\title{
Commentary on the clinical management of metabolic syndrome: why a healthy lifestyle is important
}

Michel de Lorgeril

\begin{abstract}
Metabolic syndrome (MS) is associated with an increased risk of type 2 diabetes mellitus and cardiovascular diseases. There is no recognized method to manage MS. Many physicians treat the individual characteristics of MS (high blood pressure, high triglycerides, and so on) instead of the syndrome as a whole, placing particular emphasis on those components that are easily amenable to drug treatment. However, regular physical exercise and a healthy diet have been demonstrated to improve the health of a number of populations, but few studies have assessed their effects in patients with MS. A meta-analysis by Yamaoka and Tango in BMC Medicine found that a lifestyle change program (dietary counseling and encouragement to exercise) resulted in improvements in components of MS and in reducing the proportion of patients with MS. The effects may not be impressive in absolute terms, but the data should be interpreted with the heterogeneity of the included studies in mind. Because of the many adverse side effects of the drugs used to correct individual aspects of MS, this metaanalysis provides strong evidence that lifestyle changes must be the first-line approach to manage MS.

See related article http://www.biomedcentral.com/ 1741-7015/10/138/abstract
\end{abstract}

Keywords: metabolic syndrome, meta-analysis, lifestyle, triglycerides, obesity, overweight, insulin resistance, diabetes, hypertension, high-density lipoprotein

Correspondence: michel.delorgeril@ujf-grenoble.fr

Laboratoire Cœur et Nutrition, TIMC-IMAG CNRS 5525, Université Joseph Fourier, Faculté de Médecine, 38054 La Tronche, Grenoble, France

\section{Commentary}

Metabolic syndrome (MS), defined as a cluster of biological and physiological characteristics, is associated with an increased risk of type 2 diabetes mellitus, cardiovascular disease (CVD), and all-cause mortality $[1,2]$.

Several definitions of MS have been given, depending on the respective fields of specialty of the experts (cardiology, diabetes, obesity, and so on). According to the American Heart Association [1], MS is diagnosed when any three of the following criteria are associated: waist circumference $>102 \mathrm{~cm}$ in men and $>88 \mathrm{~cm}$ in women; triglycerides $>150 \mathrm{mg} / \mathrm{dl}$; high-density lipoprotein (HDL) cholesterol $<40 \mathrm{mg} / \mathrm{dl}$ in men and $<50 \mathrm{mg} / \mathrm{dl}$ in women; systolic blood pressure $>130 \mathrm{mmHg}$, diastolic blood pressure $>85 \mathrm{mmHg}$, or current use of antihypertensive medication; and fasting glucose $>100 \mathrm{mg} / \mathrm{dl}$ or current drug treatment for elevated blood glucose.

The clinical management of MS is difficult because there is no recognized method to prevent or improve the whole syndrome, the background of which is essentially insulin resistance [3]. Therefore, many physicians, depending on their own medical subspecialty, treat one particular characteristic of MS (high blood pressure, high blood glucose, and so on) instead of the syndrome as a whole. However, one of the characteristics of MS is generally more degraded than the others in most patients (overweight, high triglycerides, and so on), and it is this one that patients usually wish to have corrected.

Thus, most physicians treat each component of MS separately, laying particular emphasis on those components that are easily amenable to drug treatment. In fact, it is easier to prescribe a drug to lower blood pressure, blood glucose or triglycerides rather than initiating a long-term strategy to change people's lifestyle (exercise more, eat better) in the hope that they will ultimately lose weight and tend to have lower blood pressure, blood glucose and triglycerides. 
This is a critical issue because it is still not clear whether type 2 diabetes and CVD ultimately result from a deleterious lifestyle or from the specific abnormalities that characterize MS. In other words: is it the lack of physical exercise that is harmful, or a low HDL level?

Recent data regarding the use of drugs to raise $\mathrm{HDL}$ levels suggest that a marked increase in HDL does not result in significant health benefits, and that it may be more important to correct the lifestyle; that is, more skeletal muscle activity associated with more physical exercise rather than artificially increasing HDL using a drug [4-6].

In addition, there is still controversy regarding the best diet to reduce the risk of type 2 diabetes and to prevent or improve MS [7-12].

As a consequence, many physicians think that the first priority to protect their patients is to help them stop smoking and lower their blood cholesterol (usually with a statin), hoping that this approach will reduce the risk of CVD complications. However, both smoking cessation $[13,14]$ and use of statins - causing a decrease in physical activity because of their toxicity on skeletal muscle $[15,16]$ - can lead to weight gain, deterioration of some MS characteristics and increase the risk of new-onset type 2 diabetes $[17,18]$.

It is only on reconsideration that some physicians may try to improve their patient's diet and encourage them to exercise more. At that time, as smoking cessation and lower cholesterol levels due to use of a statin may have considerably improved their risk factor status, patients might be unwilling to further change their lifestyle. Also, many of them may be reluctant to exercise because of the toxic effects of statins on their muscles. As a consequence, proactive physicians prescribe drugs to lower blood pressure, blood glucose and triglycerides to further improve the risk factor status of their patients, and many patients inevitably develop the many adverse effects of these drugs [19-22], in particular increased insulin resistance. This is definitely a vicious circle, and unfortunately a realistic description of what happens in daily medical practice.

And yet, regular physical exercise and a healthy diet have been unequivocally demonstrated to improve the health of a number of populations [23-27]. However, few studies have assessed their effects in individuals with MS [28-32].

In this context, the systematic review and meta-analysis performed by Yamaoka and Tango, examining the effects of lifestyle changes on MS, is welcome [33]. They have identified eight randomized controlled trials and included them in a meta-analysis. They found that a lifestyle change program (essentially dietary counseling and encouragement to exercise more) resulted in significant improvements in most components of MS and in reducing the proportion of patients with MS in comparison to conventional approaches [33].

The effects may not be impressive in absolute terms, but the data should be interpreted with the heterogeneity of the included studies in mind. In fact, variability is quite wide in terms of study duration and the types of lifestyle changes. For instance, some investigators used either the DASH ('Dietary Approaches to Stop Hypertension') or the Mediterranean diet, whereas others used low-fat diets.

The studied populations also are a source of heterogeneity. Some studies were conducted in Europe, either Northern Europe (UK and Finland) or Southern Europe (Italy and Spain), and others in the USA and in Iran. In fact, it is likely that the traditional lifestyles in these various parts of the world and the expected responses of the studied populations to any intervention will be different. Finally, there was no attempt in this meta-analysis to adjust for the drugs used in these highly diverse populations. As discussed above, drugs remain the preferred approach of many physicians in most European countries and in the USA to improve or suppress the abnormalities associated with MS. This factor may have been a major confounder in some of the included trials.

Despite these limitations, and also because of the many adverse side effects of the drugs used to correct some aspects of MS, as the authors conclude, this metaanalysis provides strong evidence that long-term lifestyle changes must be the first-line approach to reduce the prevalence of MS and of its complications.

\section{Acknowledgements}

MdeL discloses receiving research grants (through the Grenoble University School of Medicine) from the European Community and Barilla Soc.

\section{Authors' information}

MdeL is a cardiologist and nutritionist, and full-time researcher at the School of Medicine of the University of Grenoble (France) and at the French National Centre for Scientific Research (CNRS) in the Life Science Department.

\section{Competing interests}

The author declares that he has no competing interests.

Received: 25 October 2012 Accepted: 14 November 2012

Published: 14 November 2012

\section{References}

1. Grundy SM, Cleeman Jl, Daniels SR, Donato KA, Eckel RH, Franklin BA, Gordon DJ, Krauss RM, Savage PJ, Smith SC Jr, Spertus JA, Costa F, for the American Heart Association and National Heart, Lung, and Blood Institute: Diagnosis and management of the metabolic syndrome: an American Heart Association/National Heart, Lung, and Blood Institute scientific statement. Circulation 2005, 112:2735-2752.

2. Wilson PWF, D'Agostino RB, Parise H, Sullivan L, Meigs JB: Metabolic syndrome as a precursor of cardiovascular disease and type 2 diabetes mellitus. Circulation 2005, 112:3066-3072.

3. Reaven GM: Role of insulin resistance in human disease. Diabetes 1988, 37:1595-1607.

4. Barter P: Raising HDL-C can be achieved by both lifestyle changes and pharmacological means. Introduction. Atheroscler Supp/ 2011, 12:265-266. 
5. Kastelein JJ, van Leuven SI, Burgess L, Evans GW, Kuivenhoven JA, Barter PJ, Revkin JH, Grobbee DE, Riley WA, Shear CL, Duggan WT, Bots ML, RADIANCE 1 Investigators: Effect of torcetrapib on carotid atherosclerosis in familial hypercholesterolemia. N Engl J Med 2007, 356:1620-1630.

6. Barter PJ, Caulfield M, Eriksson M, Grundy SM, Kastelein JJ, Komajda M Lopez-Sendon J, Mosca L, Tardif JC, Waters DD, Shear CL, Revkin JH, Buhr KA, Fisher MR, Tall AR, Brewer B, ILLUMINATE Investigators: Effects of torcetrapib in patients at high risk for coronary events. $N$ Engl J Med 2007, 357:2109-2122

7. Grundy SM, Hansen B, Smith SC Jr, Cleeman Jl, Kahn RA: Clinical management of metabolic syndrome: report of the American Heart Association/National Heart, Lung, and Blood Institute/American Diabetes Association conference on scientific issues related to management. Arterioscler Thromb Vasc Biol 2004, 24:e19-24.

8. de Lorgeril M, Salen P: New insights into the health effects of dietary saturated and omega- 6 and omega- 3 polyunsaturated fatty acids. BMC Med 2012, 10:50

9. Tortosa A, Bes-Rastrollo M, Sanchez-Villegas A, Basterra-Gortari FJ, NuñezCordoba JM, Martinez-Gonzalez MA: Mediterranean diet inversely associated with the incidence of metabolic syndrome: the SUN prospective cohort. Diabetes Care 2007, 30:2957-2959.

10. Azadbakht L, Mirmiran P, Esmaillzadeh A, Azizi T, Azizi F: Beneficial effects of a dietary approaches to stop hypertension eating plan on features of the metabolic syndrome. Diabetes Care 2005, 28:2823-2831.

11. McKeown NM, Meigs JB, Liu S, Saltzmann E, Wilson PW, Jacques PF: Carbohydrate nutrition, insulin resistance, and the prevalence of the metabolic syndrome in the Framingham Offspring Cohort. Diabetes Care 2004, 27:538-546.

12. Fogli-Cawley JJ, Dwyer JT, Saltzman E, McCullough ML, Troy LM, Meigs JB, Jacques PF: The 2005 dietary guidelines for Americans and risk of the metabolic syndrome. Am J Clin Nutr 2007, 86:1193-1201.

13. Aubin HJ, Farley A, Lycett D, Lahmek P, Aveyard P: Weight gain in smokers after quitting cigarettes: meta-analysis. BMJ 2012, 345:e4439.

14. Luo J, Rossouw J, Tong E, Giovino GA, Lee C, Chen C, Ockene JK, Qi L, Margolis KL: Smoking cessation, weight gain, and risk of type 2 diabetes mellitus among postmenopausal women. Arch Intern Med 2012, 172:438-440

15. Hoffman KB, Kraus C, Dimbil M, Golomb BA: A survey of the FDA's AERS database regarding muscle and tendon adverse events linked to the statin drug class. PLOS One 2012, 7:e42866.

16. Cham S, Evans MA, Denenberg JO, Golomb BA: Statin-associated musclerelated adverse effects: a case series of 354 patients. Pharmacotherapy 2010, 30:541-553.

17. Koh KK, Quon MJ, Han SH, Lee Y, Kim SJ, Shin EK: Atorvastatin causes insulin resistance and increases ambient glycemia in hypercholesterolemic patients. J Am Coll Cardiol 2010, 55:1209-1216.

18. Culver AL, Ockene IS, Balasubramanian R, Olendzki BC, Sepavich DM, Wactawski-Wende J, Manson JE, Qiao Y, Liu S, Merriam PA, Rahilly-Tierny C, Thomas F, Berger JS, Ockene JK, Curb JD, Ma Y: Statin use and risk of diabetes mellitus in postmenopausal women in the Women's Health Initiative. Arch Intern Med 2012, 172:144-152

19. Opie LH, Yellon DM, Gersh BJ: Controversies in the cardiovascular management of type 2 diabetes. Heart 2011, 97:6-14.

20. Kuperstein R, Sasson Z: Effects of antihypertensive therapy on glucose and insulin metabolism and on left ventricular mass: a randomized, double-blind, controlled study of 21 obese hypertensives. Circulation 2000, 102:1802-1806

21. Weidmann P, Ferrier C, Saxenhofer H, Uehlinger DE, Trost BN: Serum lipoproteins during treatment with antihypertensive drugs. Drugs 1988, 35:118-134.

22. Lardinois CK, Neuman SL: The effects of antihypertensive agents on serum lipids and lipoproteins. Arch Intern Med 1988, 148:1280-1288.

23. Wartburton DE, Nicol CW, Bredin SS: Health benefits of physical activity: the evidence. CMAJ 2006, 174:801-809.

24. Barengo NC, Hu G, Lakka TA, Pekkarinen H, Nissinen A, Tuomilehto J: Low physical activity as a predictor for total and cardiovascular disease mortality in middle-aged men and women in Finland. Eur Heart J 2004, 25:2204-2211.

25. Wen CP, Wai JP, Tsai MK: Minimum amount of physical activity for reduced mortality and extended life expectancy: a prospective cohort study. Lancet 2011, 378:1244-1253.
26. de Lorgeril M, Renaud S, Mamelle N, Salen P, Martin JL, Monjaud I, Guidollet J, Touboul P, Delaye J: Mediterranean alpha-linolenic acid-rich diet in secondary prevention of coronary heart disease. Lancet 1994, 343:1454-1459.

27. de Lorgeril M, Salen P, Martin JL, Monjaud I, Delaye J, Mamelle N: Mediterranean diet, traditional risk factors, and the rate of cardiovascular complications after myocardial infarction: final report of the Lyon Diet Heart Study. Circulation 1999, 99:779-785.

28. Smutok MA, Reece C, Kokkinos PF: Aerobic versus strength training for risk factor intervention in middle-aged men at high risk for coronary heart disease. Metabolism 1993, 42:177-184.

29. Pratley RE, Hagberg JM, Dengel DR, Rogus EM, Muller DC, Goldberg AP. Aerobic exercise training-induced reductions in abdominal fat and glucose-stimulated insulin responses in middle-age and older men. J Am Geriatr Soc 2000, 48:1055-1061.

30. Blumenthal JA, Sherwood A, Gullette EC: Exercise and weight loss reduce blood pressure in men and women with mild hypertension. Arch Intern Med 2000, 160:1947-1958.

31. Dengel DR, Hagberg JM, Pratley RE, Rogus EM, Goldberg AP: Improvements in blood pressure, glucose metabolism, and lipoprotein lipids after aerobic exercise plus weight loss in obese, hypertensive middle-aged men. Metabolism 1998, 47:1075-1082.

32. Tuomilehto J, Lindstrom J, Eriksson JG: Prevention of type 2 diabetes by changes in lifestyle among subjects with impaired glucose tolerance. N Engl J Med 2001, 344:1343-1350.

33. Yamaoka K, Tango T: Effects of lifestyle modification on metabolic syndrome: a systematic review and meta-analysis. BMC Med

\section{Pre-publication history}

The pre-publication history for this paper can be accessed here: http://www.biomedcentral.com/1741-7015/10/139/prepub

\section{doi:10.1186/1741-7015-10-139}

Cite this article as: de Lorgeril: Commentary on the clinical management of metabolic syndrome: why a healthy lifestyle is important. BMC Medicine 2012 10:139.

\section{Submit your next manuscript to BioMed Central and take full advantage of:}

- Convenient online submission

- Thorough peer review

- No space constraints or color figure charges

- Immediate publication on acceptance

- Inclusion in PubMed, CAS, Scopus and Google Scholar

- Research which is freely available for redistribution

Submit your manuscript at www.biomedcentral.com/submit
C Biomed Central 